\title{
ASSESSMENT OF ADENOSINE DEAMINASE (ADA) LEVEL IN PREGNANT EWES IN RELATION TO LIVER FUNCTION TEST AND SOME OXIDANT INDICATOR
}

\author{
GHADA A.E. MOHAMED ${ }^{1}$ and NASSER S. ABOU-KHALI ${ }^{2}$ \\ ${ }^{1}$ Biochemistry and Nutritional Deficiency Diseases Unit, Animal Health Research Institute, Assiut Branch \\ Agriculture Research Center, Egypt. \\ ${ }^{2}$ Faculty of Medicine, Assiut University, Department of Medical Physiology.
}

Received: 30 March 2017; $\quad$ Accepted: 5 July 2017

\begin{abstract}
Pregnancy represents a major challenge to animal based on the analysis of immunological and metabolic responses. Thus, the aim of this study to assess the potential changes in adenosine deaminase (ADA) enzyme activity level, representative indicators of liver function, and some markers of oxidative stress. This study was conducted on 36 Saidi ewes divided into four equal groups $(n=9)$. The first group (non pregnant) was kept as control, while the other three groups were classified according to the time intervals of pregnancy (4-5, 11-12 and 16-17 weeks). The study showed that ADA level exhibited a bimodal pattern with highly significant increase in early pregnancy, decline in mid pregnancy, and further increase in late pregnancy. A significant increase in total protein (TP) was observed at early pregnancy, and returned to the basal level followed by further significant decrease at the late stage of pregnancy. Albumin (ALB) and triglyceride (TG) undergone significant decreased at the late stage. Mean while, total bilrubin (TB), total cholesterol (TC) and aspartate aminotransferase (AST) remained significantly lower than the pre-pregnancy values. The maximum level of gamma-glutamyl-transferase (GGT) appeared at early pregnancy, and the minimum level was observed at the late period. Malondialdhyde (MDA) has undergone a significant reduction along all time intervals in comparison to its non pregnant value. At the mid and late periods, significant reductions in nitric oxide (NO) levels were observed relative to the non pregnant values. Using Pearson correlation, ADA correlated positively with TP, globulin (GLOB) and GGT, and negatively with TB. In conclusion, the pregnancy in Saidi ewes is marked with biphasic modulation in ADA, impairment in liver functionality and adaptation in the face of oxidative stress at least on the level of lipid peroxidation. In addition, monitoring of the biochemical measurements in the blood of ewes in the different stages of pregnancy gives the basis for carrying out the treatment more effectively, and implementation of preventive measures against the metabolic disorders of ewes in order to reduce the economic losses.
\end{abstract}

Key words: Pregnancy, Saidi ewes, adenosine deaminase, liver function, oxidant markers.

\section{INTRODUCTION}

Pregnancy is associated with adaptations in the maternal systemic immunity which are responsible for the observed alterations in disease susceptibility and severity as pregnancy progresses (Pazos et al., 2012).

The main biological activity of adenosine deaminase (ADA) is to protect lymphocytes from toxic effects of 2- deoxyadenosine triphosphate, and deoxyadenosine diphosphate, which depress immune functions (Desrosiers et al., 2007). The ADA regulates the

Corresponding author: Dr. GHADA A.E. MOHAMED E-mail address:dr_kada2012@yahoo.com

Present address: Biochemistry and Nutritional Deficiency Diseases Unit, Animal Health Research Institute, Assiut Branch Agriculture Research Center, Egypt. cellular mechanisms associated with blood flow, vasodilatation, angiogenesis and proliferation (Aydin et al., 2010). By catalyzing the irreversible deamination of adenosine into inosine, ADA represents a critical checkpoint in cell mediated immunity (Franco et al., 1997; Köse et al., 2001).

Multiple modulatory patterns in ADA had been recorded during pregnancy (Yoneyama et al., 2002; Lee et al., 2007; Atakisi et al., 2009; Aydin et al., 2010). It increases in the hepatocellular affections which accompany with immuno-stimulatory responses (Atakisi et al., 2006).

Metabolic profile especially that related to hepatic function is not only of outmost significance in monitoring the health condition of animal to avoid economical loss in farming industry, but also in 
predicting prepartum disorders as fatty liver (Khatun et al., 2011). Ovine pregnancy is a one of the most energy consuming phases in ewes as manifested by high mobilization rate of energetic resources culminating at negative energy balance aiming to maintain adequate nutritional supplement to the fetus (Lotfollahzadeh et al., 2016; Nawito et al., 2016). Liver, as a central region for wide array of metabolic pathways, seemed to be overloaded by fetal and maternal demands (Lotfollahzadeh et al., 2016). However, the metabolic responses of liver to pregnancy varied greatly in different breeds of ewes (Deghnouche et al., 2013; Kandiel et al., 2016; Lotfollahzadeh et al., 2016).

Increased consumption of oxygen and energy substrates, and metabolic demands of placenta during pregnancy predispose to increased production of reactive oxygen species leading to oxidative stress (Erisir et al., 2009), but whether the antioxidant machinery able to counteract this situation remains a major question. In the light of studies on Awassi, Anatolian Merinos and cross-bred ewes, the considerable elevation in glutathione redox system overcame the high rate of lipid peroxidation at least in the mid gestation period (Erisir et al., 2009; Aydin et al., 2010).

As a pro-oxidant species, nitric oxide is generated in vivo as a consequence of multiple aerobic metabolic pathways and contributes in many regulatory aspects of pregnancy including implantation, placental blood flow, and relaxation of the uterine muscle (Maul et al., 2003; Biondi et al., 2005; Kandiel et al., 2016). A close look to literature revealed a broad spectrum of conflict data regarding the changes in NO levels of pregnant ewes. In comparison with cyclic ewes, NO increased, decreased or showed biphasic pattern of response (Vonnahme et al., 2005; Aydin et al., 2010; Kandiel et al., 2016).

Saidi sheep is the oldest Egyptian breed located in Upper Egypt with fatty tail and coarse wool. They are raised mainly for lamb production in addition to wool as a secondary product. The demand for this breed increases due to its high rate of conception (ElHommosi and Abdel- Hafiz, 1982) and twining (Galal, 1987).

Therefore, the aim of this study is to shed the light on the changes in ADA activity level, liver function parameters, MDA and NO levels in pregnant Saidi ewes, and the correlative relationship between ADA and the other parameters.

\section{MATERIALS AND METHODS}

\section{Animals:}

A total number of 36 apparently clinical healthy Saidi ewes (2.5-3 years old) from sheep farm at Assiut city were fed on the same formulated rations $(50 \%$ yellow corn, $35 \%$ bran, $10 \%$ soya-beans meal, $3 \%$ ground corn cobs, $2 \%$ ground lime stone and $1 \%$ common salt). Fresh water and mineral supplements were available ad libitum. Ewes were free of disease, and internal and external parasites. They were divide into four equal groups $(n=9)$. Non pregnant ewes were kept as control, while the other three groups were divided according to the time intervals of pregnancy (4-5, 11-12 and 16-17 weeks).

\section{Sample preparation and biochemical measurements:}

Blood serum samples were collected through jugular vein puncture, and centrifuged at $1.800 \mathrm{rpm}$ for 15 min to obtain clear non haemolysed sera. Sera were kept in Eppendrof tubes, and stored at $-20{ }^{\circ} \mathrm{C}$ until analysis later on.

Adenosine deaminase (ADA) enzyme activity level was determined by colorimetric Kit (Diazyme Laboratories) according to Kobayashi et al. (1993). Total protein (TP), albumin (ALB), total bilirubin (TB), total cholesterol (TC), and triglyceride (TG) were assessed by commercially available kits (Diamond Diagnostic, Egypt). Globulin (GLOB) mathematically calculated from $\mathrm{TP}$ and albumin (ALB). Aspartate aminotransferase (AST), and gamma-glutamyl-transferase (GGT) were estimated by kinetic kits (Spectrum Diagnostic, Egypt). Malondialdhyde (MDA) was determined by thiobarbaturic acid reaction according to the method of (Ohkawa et al., 1979). Nitric oxide (NO) was measured as nitrite concentration colorimetrically using the method of (Ding et al., 1988).

\section{Statistical analysis:}

Data were expressed as means \pm standard error of the mean (SEM). Data were compared at the various time points using one way ANOVA followed by Duncan post-test. The significance of correlation coefficient between the various biochemical parameters was performed using Person test. All statistical analysis was carried by (SPSS, 2000). Differences were considered statistically significant at $P<0.05$.

\section{RESULTS}

Table (1) illustrated the changes in the levels of serum biochemical parameters in non pregnant and throughout the different periods in pregnant ewes.

The biphasic pattern of modulation in ADA levels was evident by its significant increase at 4-5 weeks of pregnancy followed by its significant decrease thereafter in comparison with the pre-gestation values. TP level showed a significant increase at 4-5 weeks of pregnancy, then returned to the basal level followed by further significant decrease at the end of pregnancy. ALB levels remained relatively stable until 11-12 weeks of pregnancy, and then suddenly 
decrease at the final time point. A significant increase in GLOB level was observed at 4-5 weeks of pregnancy followed by return to the initial value during the remaining periods of pregnancy. TP, TC and AST levels remained significantly lower than the pre-gestational values along the entire course of pregnancy. TG level significantly decreased at the final stage of pregnancy as compared to the previous time points including pre-gestational one. The maximum level of GGT appeared at 4-5 weeks of pregnancy. Its level at 11-12 weeks of pregnancy was not significantly different from the pre-gestational value, and the minimum level was observed at the last time point. In comparison with the pre-gestational values, MDA levels had undergone a significant reduction along all time points, and the minimum levels were found since 11-12 weeks of pregnancy. At the mid and late periods, significant reductions in NO levels were observed relative to the initial values.

As shown in table (2), ADA correlated positively with TP, GLOB and GGT, and negatively with TB. No significant correlation was found between ADA on one side and ALB, AST, TC, TG, MDA or NO on the other side.

Table 1: Serum biochemical parameters in the pregnant Saidi ewes along different time intervals versus their non pregnant levels

\begin{tabular}{lcccc}
\hline \multicolumn{1}{c}{ Time interval } & $\begin{array}{c}\text { Non-Pregnant } \\
\text { (Control) }\end{array}$ & $\begin{array}{c}4-5 \text { weeks } \\
\text { Parameter }\end{array}$ & $\begin{array}{c}11-12 \text { weeks } \\
\text { (mid gestation) }\end{array}$ & $\begin{array}{c}16-17 \text { weeks } \\
\text { (Late gestation) }\end{array}$ \\
\hline ADA(U/L) & $34.76 \pm 0.7^{\mathrm{b}}$ & $43.84 \pm 1.64^{\mathrm{a}}$ & $35.81 \pm 0.65^{\mathrm{b}}$ & $37.76 \pm 1.42^{\mathrm{b}}$ \\
\hline TP $(\mathrm{g} / \mathrm{dL})$ & $6.16 \pm 0.24^{\mathrm{b}}$ & $8.43 \pm 0.43^{\mathrm{a}}$ & $5.79 \pm 0.27^{\mathrm{b}}$ & $4.9 \pm 0.09^{\mathrm{c}}$ \\
\hline ALB $(\mathrm{g} / \mathrm{dL})$ & $3.38 \pm 0.05^{\mathrm{a}}$ & $3.45 \pm 0.13^{\mathrm{a}}$ & $3.04 \pm 0.22^{\mathrm{ab}}$ & $2.73 \pm 0.15^{\mathrm{b}}$ \\
\hline GLOB $(\mathrm{g} / \mathrm{dL})$ & $2.78 \pm 0.08^{\mathrm{b}}$ & $4.97 \pm 0.44^{\mathrm{a}}$ & $2.76 \pm 0.27^{\mathrm{b}}$ & $2.17 \pm 0.25^{\mathrm{b}}$ \\
\hline TB $(\mathrm{mg} / \mathrm{dL})$ & $0.46 \pm 0.02^{\mathrm{a}}$ & $0.24 \pm 0.03^{\mathrm{c}}$ & $0.30 \pm 0.01^{\mathrm{bc}}$ & $0.33 \pm 0.04^{\mathrm{b}}$ \\
\hline AST $(\mathrm{U} / \mathrm{L})$ & $108.14 \pm 1.65^{\mathrm{a}}$ & $81.61 \pm 4.43^{\mathrm{b}}$ & $88.63 \pm 2.68^{\mathrm{b}}$ & $87.63 \pm 4.69^{\mathrm{b}}$ \\
\hline GGT $(\mathrm{U} / \mathrm{L})$ & $57.00 \pm 2.11^{\mathrm{b}}$ & $68.14 \pm 4.97^{\mathrm{a}}$ & $50.99 \pm 3.6^{\mathrm{bc}}$ & $41.74 \pm 0.8^{\mathrm{c}}$ \\
\hline TC $(\mathrm{mg} / \mathrm{dL})$ & $80.23 \pm 3.64^{\mathrm{a}}$ & $65.48 \pm 1^{\mathrm{b}}$ & $62.34 \pm 1.71^{\mathrm{b}}$ & $60.46 \pm 2.92^{\mathrm{b}}$ \\
\hline TG $(\mathrm{mg} / \mathrm{dL})$ & $20.24 \pm 0.18^{\mathrm{ab}}$ & $23.62 \pm 1.1^{\mathrm{a}}$ & $21.99 \pm 1.24^{\mathrm{a}}$ & $17.04 \pm 2.09^{\mathrm{b}}$ \\
\hline MDA $(\mathrm{nmol} / \mathrm{mL})$ & $3.92 \pm 0.27^{\mathrm{a}}$ & $3.46 \pm 0.16^{\mathrm{b}}$ & $2.91 \pm 0.08^{\mathrm{c}}$ & $2.92 \pm 0.12^{\mathrm{c}}$ \\
\hline NO $(\mu \mathrm{mol} / \mathrm{L})$ & $21.58 \pm 2.88^{\mathrm{a}}$ & $19.04 \pm 2.27^{\mathrm{ab}}$ & $13.98 \pm 1.18^{\mathrm{b}}$ & $14.81 \pm 0.2^{\mathrm{b}}$ \\
\hline & & & & \\
\hline
\end{tabular}

Results are expressed as means \pm SEM of 9 ewes per group.

ADA, adenosine deaminase; TP, total protein; ALB, albumin; GLOB, globulin; TB, total bilirubin; AST, asparatate aminotransferase; GGT, gamma-glutamyl-transferase; TC, total cholesterol; TG, triglyceride; MDA, malondialdhyde; NO, nitric oxide.

Different letters indicate significance difference at $p<0.05$ (one way ANOVA followed by Duncan post-test).

Table 2: Correlation coefficient between adenosine deaminase activity level and the other biochemical parameters in the pregnant Saidi ewes among all time intervals

\begin{tabular}{ccccccccccc}
\hline & TP & ALB & GLOB & TB & AST & GGT & TC & TG & MDA & NO \\
\hline $\begin{array}{c}\text { Pearson } \\
\text { correlation }\end{array}$ & 0.611 & 0.301 & 0.509 & -0.434 & 0.090 & 0.472 & 0.073 & 0.037 & 0.277 & -0.445 \\
\hline $\begin{array}{c}p \text { value } \\
\text { 0.001 }\end{array}$ & 0.127 & 0.007 & 0.024 & 0.657 & 0.013 & 0.719 & 0.855 & 0.102 & 0.065 \\
\hline
\end{tabular}




\section{DISCUSSION}

The major findings of this study were the biphasic pattern of fluctuation in ADA that followed almost exactly the fluctuation in GLOB in the pregnant ewes. A marked exhaustion of energetic substrates along with impairment of liver functionality and surprising reduction in pro-oxidant and vasoactive reflectors were also found. These findings constitute a contribution towards better understanding of physiological processes in the pregnant ewes and a platform for pregnancy-related diagnostic purposes.

The biphasic pattern of ADA in the current study is in harmony with previous findings in other animal species including sheep (Sim and Maguire, 1970; Aydin et al., 2010). The possible contributory factor involved in a marked increase of ADA in early pregnancy is the urgent need to degrade the elevated adenosine and to maintain its kinetic equilibrium (Lee et al., 2007). However, the obvious decrease of ADA in late pregnancy may be emerged from the increase in inhibitory influences of pregnancy-related hormones such as estradiol and cortisol (Melzig and Paun, 1992). This is also associated with increased concentration of adenosine which could play a key role in the hemodynamic aspects of uterine and placental circulations (Lee et al., 2007).

In accordance with (Gonzales-Montana et al., 1994), TP and GLOB levels significantly increased in this study at the first month of pregnancy relative to their pre-gestational values. This could be a result of embryo-specific protein production during the period of maternal recognition of pregnancy, which can either be confined to the uterus or may appear in maternal blood (Manns and Lewing, 1986).

In this study, the increase in TP in first stage of pregnancy was in synchronization with the increase in GLOB. The decreased TP in late pregnancy is in agreement with that reported in Saidi ewes by (Teleb et al., 2014). Sema et al. (2009) recorded a decrease in TP levels in days 150 and 120 of gestation, respectively, in ewes. The decrease in serum $\mathrm{TP}$ in late pregnancy may be due to the need of the fetus to synthesize all proteins from the amino acids derived from mother, especially during late pregnancy where the growth of the fetus increases exponentially reaching a maximum level (Safsaf et al., 2012).

The significant decreases of TP, ALB and GLOB in late pregnancy are in consistent with previous investigations on Makuii and Akkaraman ewes (Batavani et al., 2006; Balıkc1 et al., 2007). These outcome responses may be related to the facts that fetal synthetic machinery depends completely on maternal proteins, and the increase in nutritive fetal and placental requirements secondary to acceleration in fetal growth rate reaching maximum level during the late stages (Jainudeen and Hafez, 2000). High GLOB consumption in colostrum production 3-4 weeks prepartum (Davson and Segal, 1980) may give indication about its depletion in the maternal blood. Moreover, it could attributed to the rapid extraction of immunoglobulin from plasma during the last months of pregnancy, when colostrum formed in the mammary gland, as well as the increase needs to proteins for the fetal development (Castillo et al., 1999; Antunović et al., 2004).

In this study, the significant increase in TB at the late pregnancy relative to the early stage is parallel with the observations of (Balıkcı et al., 2007; Gürgöze et al., 2009). Additional bilirubin derived from degradation products of fetal hemoglobin or inadequate glucuronic acid biosynthesis may be implicated in this finding, reflecting hepatic hypofunction (Gürgöze et al., 2009).

The decreases in TC and TG in the current study are in agreement with Piccione et al. (2009) in sheep who observed significant decrease especially in late gestation. This is in harmony with the fact that the adipose tissue metabolism is strictly related to insulin which stimulates lipogenesis in the pregnant ewes (Gradinski-Urbanac et al., 1986). The significant decrease in serum TG found in this study in late pregnancy is in accordance with increased concentration of these compounds in the ewes' liver as reported by Smith and Walsh (1975). The significant decrease in TC in late pregnancy had also been observed in other species such as cows (Bekeová et al., 1987) and goats (Krajničáková et al., 2003). This is probably related to the role of this substrate in ovary steroidogenesis, so that TC concentrations are under the control of complex of factors. However, Yasuhiko et al. (1981) working on pregnant pony mares reported lower TG values compared to late pregnancy, probably due to speciesspecific factors.

Contradictory, diminished insulin sensitivity during late pregnancy in ewes acts as a predisposing factor in elevating TC and TG levels (Schlumbohm et al., 1997). Thus, the marked reductions in TC level along the whole period of pregnancy and TG level at the final stage represent a major surprise in the present study. However, physiological acclimatization of pregnant ewes for their energetic and nutritive needs should be taken in consideration (Nazifi et al., 2003). The fluctuation in lipid profile during pregnancy seemed to be a sign of metabolic specificity subjected to multifactorial rearrangement in the different species, and even within the same species (Vasilenko, 2016). The hypocholesterolemia was observed in other pregnant animal species including camel and cow (Nath et al., 2005; Saeed et al., 2009). Hemodilution, reduced secretion of lipoprotein from 
liver, transport of TC to the fetal blood, increase in its use for biosynthesis of steroid hormones, accumulation in maternal tissues, increased excretion of sterols or bile acids in feces (Vasilenko, 2016), decreased its absorption from food (Zilversmit et al., 1972), and high activity of thyroid gland (Turakulov et al., 1977) may be implicated as causative mechanistic pathways for the pregnancy-related hypolipidemia.

AST levels significantly decreased along the entire course of pregnancy as reported previously (Talvekar et al., 2008; Khatun et al., 2011). Decreased AST activity throughout the gestation period was due to uterine and hormonal changes conformity with the results of (AL-Eissa and Alkahtani, 2012). However, the literature is punctuated with a growing body of controversies regarding the changes in AST levels during pregnancy in the different animal species (Tainturier et al., 1984; Yokus and Cakir, 2006; Batavani et al., 2008). Although AST values in the control group of our study are lower than other previous studies, it still within the normal range in sheep (Radostits et al., 2007; Kaneko et al., 2008).

The well manifested increase in GGT level at the beginning of pregnancy is compatible with the increase in the enzymatic parameters of liver functions in Afshari and Sakiz-Awassi crossbreed ewes (Yokus et al., 2006; Lotfollahzadeh et al., 2016). According to some authors the enzyme is tied to the metabolism of glutathione, which has an important role in the entire antioxidative status of the organism (kramer and hoffman, 1997), which is the important option for ewes in early pregnancy.

The progressive decline in NO levels throughout the pregnancy in the present study is in accordance with that observed in Anatolian Merinos and cross-bred sheep (Aydin et al., 2010), but contradictory with that observed in Barki sheep (Kandiel et al., 2016). Vonnahme et al. (2005) suggested a biphasic modulatory change in NO metabolites during ovine pregnancy as represented by increase over nonpregnant values at days 40-69 of gestation, returning to non-pregnant concentrations from days 70-100, and again increasing until the term in ewes.

In contrast to multiple lines of evidences indicating that pregnancy is a physiological status of oxidative stress (Ognik et al., 2015; Kandiel et al., 2016). The findings of this study showed a marked reduction in MDA levels during pregnancy. Although assessment the changes in maternal antioxidant capacity in different stages of pregnancy is out of scope of our study, it seemed that the possible compensatory increase in the antioxidant defense mechanism of pregnant dam (Aydin et al., 2010) is strong enough to induce reduction in the levels of pro-oxidants such as NO and MDA. This suggestion becomes clear especially when the negative correlation between ADA and antioxidant capacity (Guzel et al., 2008; Aydin et al., 2010) was taken in consideration. This does not exclude the occurrence of oxidative damage in other crucial macromolecules like DNA and protein. The differential responses to pregnancy all over the literature regarding $\mathrm{NO}$ and MDA may be linked to differences in the breed-related genetic background, type of assessed samples and nutritional status.

The ADA level increased along with corresponding increases in TP and GLOB levels in sheep naturally infected with liver Cystic echinococcosis and calves with cryptosporidiosis (Azimzadeh et al., 2015; Yarim et al., 2016), similar to the positive correlation between these two parameters in the present study. This may give indication about the denominator responsibility of ADA in immunity, as evident in this investigation by the similarity in the pattern of modulation in ADA and GLOB levels.

The positive correlation between ADA and GGT levels is matched with parallel increases in both markers in bovine liver diseases (Abd ellah et al., 2004). The action of ADA results in catabolism of adenine nucleotides with subsequent depletion in intracellular ATP (Kosenko and Kaminsky, 2010) leading to rupture of hepatic cell membrane and release of hepatic aminotransferase into the blood stream (Krishnamurthy and Krishnamurthy, 2006).

In contrast to what observed in naturally infected animals (Vakili et al., 2016), negative correlation was found in this study between ADA and TB levels. But the reduction in adenosine concentration, secondary to increase ADA activity, could contribute to the reduction in TB concentration (Zhang et al., 2011).

In conclusion, this study showed nearby copy/past image of changes in ADA and GLOB levels in the blood of pregnant ewes, overloading on liver function mostly obvious at preterm, depletion of energy reservoirs, and reduction in MDA and NO levels in the blood of pregnant ewes. Further studies are highly recommended to shed the light on the physiological response of this species to various reproductive conditions in relation to specificity in breed. Measurement the concentration of enzyme and some biochemical parameters in the blood of ewes at different physiological status gives solid basis for the regular therapy application and implementation of prophylactic measures against metabolic disturbances of ewes. Further investigations are necessary for the correct interpretation of metabolic diseases and guidelines for the management strategies in ewes under farming condition, aimed at avoiding a decline in the productive performance and consequently economic loss. 


\section{REFERENCES}

Abd ellah, M.R.; Nishimori, K.; Goryo, M.; Okada, K. and Yasuda, J. (2004): Serum adenosine deaminase activity in bovine liver diseases. Journal of Veterinary Medical Science 66, 1421-1422.

AL-Eissa, M.S. and Alkahtani, S. (2012): Gestation effects on the hematological and biochemical profile of Nubian Ibex (Capra Nubiana). Research in Zoology 2, 5-7.

Antunović, Z.; Šperanda, M.; Steiner, Z. (2004): The influence of age and the reproductive status to the blood indicators of the ewes. Archiv Tierzucht Dummerstorf 47, 265-273.

Atakisi, E.; Karapehlivan, M.; Atakisi, O.; Kontas, T. and Marasli, S. (2006): Adenosine deaminase and biochemical liver function tests in the dermatophytic cattle. Bulletin-Venterinary Institute in Pulawy 50, 481.

Atakisi, O.; Atakisi, E.; Pancarci, S.M. and Ozcan, A. (2009): Plasma and amniotic fluid nitric oxide level and adenosine deaminase activity in sheep. Journal of Applied Animal Research 35, 197-199.

Aydin, I.; Bulbul, T.; Polat, E.S. and Yazar, E. (2010): Serum antioxidant status and adenosine deaminase activity during the gestational period of sheep. Revue de Médecine Vétérinaire 161, 479-484.

Azimzadeh, K.; Farzadnia, H.; Taifebagerlu, J. and Mahan, M. (2015): Determination of total sialic acid, adenosine deaminase, malondialdehyde and heat shock protein-27 in sheep with naturally infected liver Cystic echinococcosis. Terapevticheskii Arkhiv 87, 87-92.

Balıkcı, E.; Yıldız, A. and Gürdoğan, F. (2007): Blood metabolite concentrations during pregnancy and postpartum in Akkaraman ewes. Small Ruminant Research 67, 247-251.

Batavani, R.A.; Ansari, M.H. and Asri, S. (2006): Concentrations of serum total protein and protein fractions during diestrus and pregnancy in Makuii ewes. Comparative Clinical Pathology 15, 227-230.

Batavani, R.A.; Ghasemzadeh, M. and Kheradmand, A. (2008): Changes of enzyme activities in ovine fetal fluids and maternal blood serum with gestational age. Comparative Clinical Pathology 17, 105-109.

Bekeová, E.; Elečko, J.; Hendrichovský, V.; Choma, J. and Krajničáková, M. (1987): The effect of beta-carotene on the changes in $\mathrm{T} 4$ and cholesterol concentrations in calving heifers before and after parturition. Veterinary Medicine (Praha) 32, 459-468.

Biondi, C.; Pavan, B.; Lunghi, L.; Fiorini, S. and Vesce, F. (2005): The role and modulation of the oxidative balance in pregnancy. Current Pharmaceutical Design 11, 2075-2089.

Castillo, C.; Hernandez, J.; Lopez-Alonso, M.; Miranda, M. and Benedito, J.L. (1999): Effect of physiological stage and nutritional management on some serum metabolite concentrations in Assaf ovine breed. Archiv Tierzucht Dummerstorf 42, 377-386.

Desrosiers, M.D.; Katherine, M.C.; Fakir, M.J.; Stephens, L.A.; Jama, F.M.; Shameli, A.; Mehal, W.Z.; Santamaria, P. and Shi, Y. (2007): Adenosine deamination sustains dendritic cell activation in inflammation. The Journal of Immunology 179:1884-1892.

Davson, H. and Segal, M.B. (1980): Pregnancy: maintenance and prevention, introduction to physiology. In: Control of reproduction. Academic Press, London, 258-288.

Deghnouche, K.; Tlidjane, M.; Meziane, T. and Touabti, A. (2013): Influence of physiological stage and parity on energy, nitrogen and mineral metabolism parameters in the Ouled Djellal sheep in the Algerian Southeast arid area. African Journal of Agricultural Research 8, 1920-1924.

Ding, A.H.; Nathan, C.F. and Stuchr, D.J. (1988): Release of reactive nitrogen intermediate and reactive oxygen intermediate from mouse peritoneal macrophages. Comparison of activating cytokines and evidence for independent production. Journal of Immunology 141, 2407-2412.

El-Hommosi, F.F. and Abdel-Hafiz, G.E. (1982): Reproductive performance of Ossimi and Saidi sheep under two pre- pubertal planes of nutrition. Assiut Veterinary Medical Journal 10, 61- 66 .

Erisir, M.; Benzer, F. and Kandemir, F.M. (2009): Changes in the rate of lipid peroxidation in plasma and selected blood antioxidants before and during pregnancy in ewes. Acta Veterinaria Brno 78, 237-242.

Franco, R.; Casadó, V.; Ciruela, F.; Saura, C.; Mallol, J.; Canela, E.I. and Lluis, C. (1997): Cell surface adenosine deaminase: much more than an ectoenzyme. Progress in Neurobiology 52, 283-294.

Galal, E.S.E. (1987): Sheep and goat production and research in Egypt. In: Small Ruminants in the Near East. FAO Animal Production Health Bulletin 54, 117- 155.

Gonzales-Montana, J.R.; Alonso-Diez, A.J.; AlonsoAlonso, M.P.; Prieto-Montana, F.; GarciaPartida, P. and Trenti, F. (1994): Serum protein levels during pregnancy in sheep. Proccedings of the $18^{\text {th }}$ World Buiatrics Congress, Bologna, Italy, 1181-1184.

Gradinski-Urbanac, B.; Mitin, V.; Mikulec, K. and Karadjole, I. (1986): Triglycerides and phospholipid values in sheep serum in the course of a year. Veterinary Archiv 55, 29-31. 
Gürgöze, S.Y.; Zonturlu, A.K.; Özyurtlu, N. and Icen, $H$. (2009): Investigation of some biochemical parameters and mineral substance during pregnancy and postpartum period in Awassi ewes. Kafkas Univ Vet Fak Derg 15, 957-963.

Guzel, M.; Askar, T.A.; Kaya, G.; Atakisi, E. and Avci, G.E. (2008): Serum sialic acids, total antioxidant capacity, and adenosine deaminase activity in cattle with theileriosis and anaplasmosis. Bulletin of the Veterinary Institute in Pulawy 52, 227-230.

Jainudeen, M.R. and Hafez, E.S.E. (2000): Gestation, prenatal physiology and parturition. In: Hafez, B., Hafez, E.S.E. (Eds.), reproduction in farm animals, $7^{\text {th }}$ ed. Williams and Wilkins, Philadelphia, PA, 140-155.

Kandiel, M.M.M.; El-Khaiat, H.M. and Mahmoud, K.G.M. (2016):Changes in some hematobiochemical and hormonal profile in Barki sheep with various reproductive statuses. Small Ruminant Research 136, 87-95.

Kaneko, J.J.; Harvey, J.W. and Bruss, M.L. (2008): Clinical biochemistry of domestic animals, $5^{\text {th }}$ ed. Academic Press, USA.

Khatun, A.; Wani, G.M.; Bhat, J.I.A.; Choudhury, A.R. and Khan, M.Z. (2011): Biochemical indices in sheep during different stages of pregnancy. Asian Journal of Animal and Veterinary Advances 6, 175-181.

Kobayashi, F.; Ikeda, T.; Marumo, F. and Sato, C. (1993): Adenosine deaminase isoenzymes in liver disease. American Journal of Gastroenterology 88, 266-271.

Köse, K.; Yazici, C. and Aşçioğlu, Ö. (2001): The evaluation of lipid peroxidation and adenosine deaminase activity in patients with Behcet's disease. Clinical Biochemistry 34, 125-129.

Kosenko, E.A. and Kaminsky, Y.G. (2010): Activation of AMP deaminase and adenosine deaminase in the liver during ammonia poisoning and hepatitis. Bulletin of Experimental Biology and Medicine 150, 36-38.

Krajničáková, M.Á.; Kováč, G.A.; Kostecký, M.A.; Valocký, I.G.; Maraček, I.M.; Šutiakova, I. and Lenhardt, L'. (2003): Selected clinicobiochemical parameters in the puerperal period of goats. Bulletin of the Veterinary Institute Pulawy 47, 177-182.

Kramer, J.W. and Hoffman, W.E. (1997): Clinical enzymology, in: Kaneko, J.J., Harvey, J.W., Bruss, M.L. (Eds.), clinical biochemistry of domestic animals. Academic Press, San Diego, London, Boston, New York, Sydney, Tokyo, Toronto, 303-325.

Krishnamurthy, G.T. and Krishnamurthy, S. (2006): Cholescintigraphic measurement of liver function: how is it different from other methods? European Journal of Nuclear Medicine and Molecular Imaging 33, 11031106.
Lee, S.J.; Hwang, H.S.; Kim, B.N.R.; Kim, M.A.; Lee, J.W.; Park, Y.W. and Kim, Y.H. (2007): Changes in serum adenosine deaminase activity during normal pregnancy. Journal of Korean Medical Science 22, 718-721.

Lotfollahzadeh, S.; Zakian, A.; Tehrani-Sharif, $M$. and Watson, D.G. (2016): Assessment the alterations of some biochemical parameters in Afshari sheep with possible metabolic disorders. Small Ruminant Research 145, 5864.

Manns, J.G. and Lewing, P.J. (1986): Protein production by sheep embryos during the period of maternal recognition of pregnancy. Canadian Journal of Physiology and Pharmacology 64, 1223-1228.

Maul, H.; Longo, M.; Saade, G.R. and Garfield, R.E. (2003): Nitric oxide and its role during pregnancy: from ovulation to delivery. Current Pharmaceutical Design 9, 359-380.

Melzig, M. and Paun, I. (1992): Modulation of adenosine deaminase activity of endothelial cells by steroids. Pharmazie 47, 394.

Nath, H.C.; Baruah, K.K.; Baruah, A.; Sarmah, H.D. and Sarmah, B.C. (2005): Serum cholesterol and protein in pre, peri and postpartum cows. Indian Veterinary Journal 82, 519-521.

Nawito, M.F.; El Hameed, A.R.A.; Sosa, A.S.A. and Mahmoud, K.G.M. (2016): Impact of pregnancy and nutrition on oxidant/antioxidant balance in sheep and goats reared in South Sinai, Egypt. Veterinary World 9, 801-805.

Nazifi, S.; Saeb, M.; Rowghani, E. and Kaveh, K. (2003): The influences of thermal stress on serum biochemical parameters of Iranian fattailed sheep and their correlation with triiodothyronine (T3), thyroxine (T4) and cortisol concentrations. Comparative Clinical Pathology 12, 135-139.

Ognik, K.; Patkowski, K.; Gruszecki, T. and Kostro, $K$. (2015): Redox status in the blood of ewes in the perinatal period and during lactation. Bulletin of the Veterinary Institute in Pulawy 59, 557-562.

Ohkawa, H.; Ohishi, N. and Yagi, K. (1979): Assay for lipid peroxides in animal tissue by thiobarbaturic acid reaction. Analytical Biochemistry 95, 351-358.

Pazos, M.; Sperling, R.S.; Moran, T.M. and Kraus, T.A. (2012): The influence of pregnancy on systemic immunity. Immunologic Research 54, 254-261.

Piccione, G.; Caola, G.; Giannetto, C.; Grasso, F.; Runzo, S.C.; Zumbo, A. and Pennisi, P. (2009): Selected biochemical serum parameters in ewes during pregnancy, post-parturition, lactation and dry period. Animal Science Papers and Reports 27, 321-330.

Radostits, O.M.; Gay, C.C.; Hinchcliff, K.W. and Constable, P.D. (2007): Veterinary medicine, a text book of the disease of cattle, horse, 
sheep, pigs and goats, $10^{\text {th }}$ ed. Sounders Company, London, UK, 2049.

Saeed, A.; Khan, I.A. and Hussein, M.M. (2009): Change in biochemical profile of pregnant camels (Camelus dromedarius) at term. Comparative Clinical Pathology 18, 139-143.

Safsaf, B.; Tlidjane, M.; Mamache, B.; Dehimi, M.A.; Boukrous, H. and Hassan, A. (2012): Influence of age and physiological status on progesterone and some blood metabolites of Ouled Djellal breed ewes in east Algeria. Global Veterinary 9, 237-244.

Schlumbohm, C.; Sporleder, H.P.; Gurtler, H. and Harmeyer, J. (1997): The influence of insulin on metabolism of glucose, free fatty acids and glycerol in normo-and hypocalcemic ewes during different reproductive states. Deutsche Tierarztliche Wochenschrift 104, 359-365.

Sema, Y.G.; Abuzer, K.Z.; Nihat, Ö. and Hasan, I.K. (2009): Investigation of some parameters and mineral substance during pregnancy and postpartum period in Awassi ewes. Üniversitesi Veteriner Fakültesi Dergisi 15, 957-963.

Sim, M.K. and Maguire, M.H. (1970): Variation in placental adenosine deaminase activity during gestation. Biology of Reproduction 2, 291-298.

Smith, R.W. and Walsh, A. (1975): The composition of the liver lipids of the ewe during pregnancy and lactation. Research in Veterinary Science 19, 230-232.

SPSS (2000): Sample Power Statistics, SPSS 11.5, Syntax Reference Guide for SPSS Base. SPSS Inc., 233 South Wacker Drive, Chicago.

Tainturier, D.; Braun, J.P.; Rico, A.G. and Thouvenot, J.P. (1984): Variations in blood composition in dairy cows during pregnancy and after calving. Research in Veterinary Science 37, 129-131.

Talvekar, B.A.; Patil, R.R.; Ingole, S.D. and Bharucha, S.V. (2008): Serum enzymatic profile of buffales during gesation, lactation and peripartum period. Indian Journal of Animal Science 78, 247-250.

Teleb, D.F.; Ahmed, N.A.H.; Tag El-Din, H.A.; Abou Elsoud, S.M. and Hassan, O.M. (2014): Study on Levels of Some blood hormonal and biochemical constituents during different reproductive status in Saidi ewes. Egyptian Journal of Sheep \& Goat Sciences 9, 105-113.

Turakulov, L.; Salakhova, N.S. and Tashkhodzhaeva, T.P. (1977):. State of the pituitary--thyroid gland system in pregnant rabbits, fetuses and newborn rabbits. Biulleten'Eksperimental'Noi Biologii i Meditsiny 83, 476-479.
Vakili, A.; Azimzadeh, K. and Rasouli, S. (2016): Determination of potential biomarker among plasma sphingosine-1-phosphate, total sialic acid and adenosine deaminase in cattle with naturally infected liver cystic echinococcosis. Kafkas` niversitesi Veteriner Fak, ltesi Dergisi 22, 179-183.

Vasilenko, T.F. (2016): Multidirectional changes in the blood cholesterol in mammals of different species during pregnancy and lactation. International Journal of Sciences: Basic and Applied Research 30, 59-70.

Vonnahme, K.A.; Wilson, M.E.; Li, Y.; Rupnow, H.L.; Phernetton, T.M.; Ford, S.P. and Magness, R.R. (2005): Circulating levels of nitric oxide and vascular endothelial growth factor throughout ovine pregnancy. The Journal of Physiology 565, 101-109.

Yarim, G.F.; Yagci, B.B.; Ertekin, A. and Kazak, F. (2016): Decreased serum adenosine deaminase activity correlated with clinical score and serum proteins in calves with cryptosporidiosis. Pakistan Journal of Zoology 48, 1033-1038.

Yasuhiko, K.A.N.O.; Sawasaki, T. and Matsui, K. (1981): Normal values of ponies under ordinary feeding conditions during gestation, lactation and growing periods. Bulletin of Equine Research Institute 18, 61-72.

Yokus, B.; Cakir, D.U.; Kanay, Z.; Gulten, T. and Uysal, E. (2006): Effects of seasonal and physiological variations on the serum chemistry, vitamins and thyroid hormone concentrations in sheep. Journal of Veterinary Medicine Series A 53, 271-276.

Yokus, B. and Cakir, U.D. (2006): Seasonal and physiological variations in serum chemistry and mineral concentrations in cattle. Biological Trace Element Research 109, 255-266.

Yoneyama, Y.; Sawa, R.; Suzuki, S.; Yoneyama, K.; Doi, D. and Araki, T. (2002): Relationship between adenosine deaminase activity and cytokine-secreting $\mathrm{T}$ cells in normal pregnancy. Obstetrics \& Gynecology 100, 754758.

Zhang, Y.; Dai, Y.; Wen, J.; Zhang, W.; Grenz, A.; Sun, H.; Tao, L.; Lu, G.; Alexander, D.C. and Milburn, M.V. (2011): Detrimental effects of adenosine signaling in sickle cell disease. Nature Medicine 17, 79-86.

Zilversmit, D.B.; Hughes, L.B. and Remington, M. (1972): Hypolipidemic effect of pregnancy in the rabbit. Journal of Lipid Research 13, 750756. 


\section{تقدير مستوى الادينوسين دى امينيز ( ADA) في النعاج العشار وعلاقته بوظائف الكبل وبعض علامات الأكسدة}

\section{غادة عبل العظيم محد , ناصر سبا أبو خليل}

Email: dr_kada2012@yahoo.com_Assiut University web-site: www.aun.edu.eg

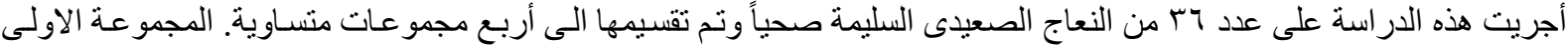

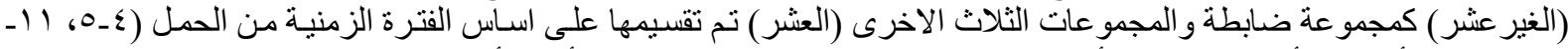

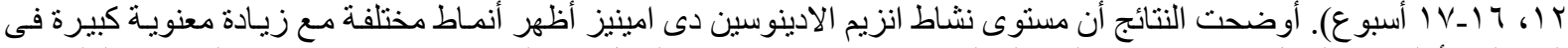

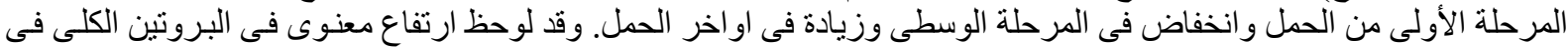

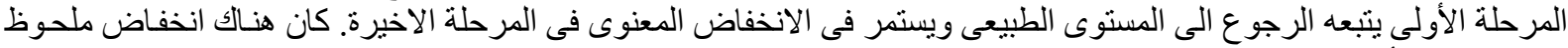

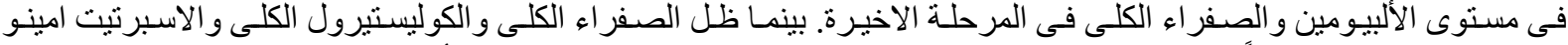

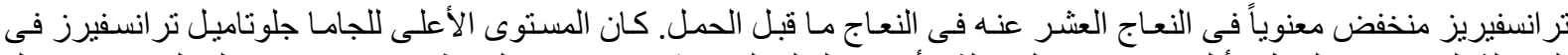

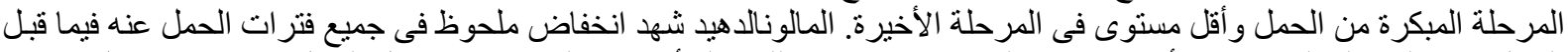

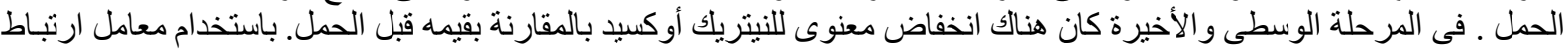

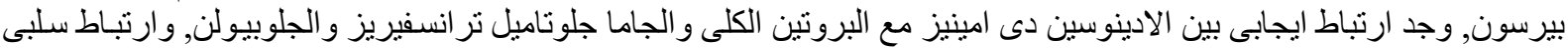

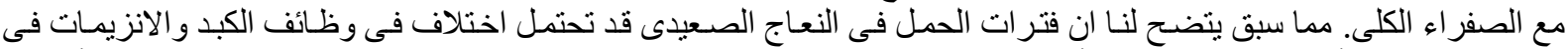

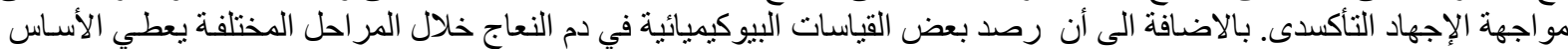
لتنفيذ العلاج بفاعلية اكثروتتفيذ إجراءات وقائية ضد اضطر ابات التمثيل الغذائي للنعاج بهدف تقليل الخسائر الاقتصادية. 